\title{
PENGARUH MODAL INSANI DAN MODAL SOSIAL TERHADAP KINERJA UMKM MAKANAN DAN MINUMAN DI SURABAYA
}

\author{
Yazied Kamal Fanani ${ }^{1}$, Dhiah Fitrayati ${ }^{2}$ \\ ${ }^{1}$ Universitas Negeri Surabaya, yaziedfanani16080554081@mhs.unesa.ac.id \\ ${ }^{2}$ Universitas Negeri Surabaya, dhiahfitrayati@unesa.ac.id
}

\section{DOI} https://doi.org/10.26740/jupe.v9n3.p84$\underline{89}$

\author{
Article history \\ Received \\ 8 June 2021 \\ Revised \\ 15 June 2021 \\ Accepted \\ 18 June 2021
}

\section{How to cite}

Fanani, Y.K., \& Fitrayati, D. (2021).

Pengaruh Modal Insani dan Modal Sosial

Terhadap Kinerja UMKM Makanan dan

Minuman Di Surabaya. Jurnal Pendidikan Ekonomi (JUPE), 9(3), 97105.

https://doi.org/10.26740/jupe.v9n3.p84$\underline{89}$

Kata Kunci: modal, insani, sosial, UMKM

Keywords: capital, human, sosial , MSMEs

\section{Corresponding author}

Yazied Kamal Fanani yaziedfanani16080554081@mhs.unesa.ac.id

\begin{abstract}
Abstrak
Situasi pandemi seperti pada saat ini merupakan musuh utama bagi para pengusaha. Mereka harus tetap menjalankan usahanya ditengah adanya pembatasan manusia untuk berkerumun. Fakta di lapangan menunjukkan UMKM makanan dan minuman justru mengalami peningkatan, tetapi peningkatan jumlah UMKM ini tidak diiringi dengan peningkatan omzet penjualan. Peran pelaku UMKM sangat dibutuhkan untuk meningkatkan omzet penjualan. Melalui modal insani seperti pengetahuan dan pengalaman dan juga modal sosial seperti relasi dari pelaku usaha dapat meningkatkan kinerja UMKM. Tujuan penelitian menganalisis pengaruh modal insani serta modal sosial akan kinerja UMKM makanan serta minuman di Surabaya. Jenis penelitian memakai pendekatan kuantitatif, total sampel sebanyak 92 pemilik usaha. Hasil dari penelitian diperoleh bahwa modal insani serta modal sosial secara simultan berpengaruh positif serta signifikan akan kinerja UMKM. Secara parsial modal insani berpengaruh positif serta signifikan terhadap kinerja UMKM dan modal sosial berpengaruh positif serta signifikan akan kinerja UMKM.
\end{abstract}

\begin{abstract}
The current pandemic situation is the main enemy for entrepreneurs. They have to keep running their business in the midst of human restrictions on crowding. Facts on the ground show that food and beverage MSMEs have actually increased, but the increase in the number of MSMEs is not accompanied by an increase in sales turnover. The role of MSME actors is needed to increase sales turnover. Through human capital such as knowledge and experience as well as social capital such as relationships from business actors can improve the performance of MSMEs. The purpose of this study is to analyze the influence of human capital and social capital on the performance of food and beverage SMEs in Surabaya. This type of research uses a quantitative approach, with a total sample of 92 business owners. The results of the study show that human capital and social capital simultaneously have a positive and significant effect on the performance of MSMEs. Partially, human capital has a positive and significant effect on the performance of MSMEs and social capital has a positive and significant effect on the performance of MSMEs.
\end{abstract}




\section{PENDAHULUAN}

Usaha Mikro kecil dan Menengah (UMKM) sebagai usaha nan diminati untuk dirintis mayoritas wirausaha di Indonesia. UMKM dipersepsikan mudah dimulai bagi wirausaha baru karena tidak membutuhkan modal nan besar. UMKM di Indonesia telah nyata mendukung pertumbuhan perekonomian negara, sehingga UMKM diharapkan mampu meningkat dari aspek jumlah serta pencapaian tingkat kesuksesannya.

Menurut Badan Pusat Statistik (2016) dari sisi sumbangan output UMKM lintas sektor, UMKM masih dominan di sektor pertanian yaitu sebesar 87,25\% sedangkan Usaha Menengah Besar (UMB) kian unggul di sektor - sektor yang bersifat penghasil barang. Hal ini menunjukkan bahwa UMKM di Indonesia masih belum kuat di sektor - sektor barang bernilai tambah tinggi.

Berdasarkan Global Competitiveness Index Report yang disampaikan World Economic Forum (2019) menunjukkan akan kelas daya saing Indonesia berada di peringkat ke-50 dari 141 Negara nan mengalami penurunan dan kian rendah dibandingkan tahun 2018 yang berada di posisi ke-45. Data tersebut mengindikasikan rendahnya kinerja UMKM di Indonesia.

Dalam kondisi pandemi Covid-19 saat ini menuntut masyarakat untuk tidak saling berkerumun untuk mencegah penyebaran virus covid-19 semakin meluas. Hal ini sangat berdampak bagi UMKM makanan dan minuman yang berada di sentra wisata kuliner yang ada di Surabaya. Omzet penjualan menurun selama masa pandemi. Akan tetapi fakta dilapangan menunjukkan bahwa jumlah UMKM di Kota Surabaya mengalami peningkatan selama masa pandemi. Dinas Koperasi dan Usaha Mikro Surabaya (2020) mencatat selama 2020 hingga 2021 jumlah UMKM meningkat hingga mencapai 40 ribu usaha yang sebelum pandemi berada dikisaran 11 ribu usaha, artinya terdapat peningkatan sebesar 29 ribu UMKM baru. Peningkatan terbesar ada di sektor kuliner. Peningkatan jumlah UMKM ini tidak di iringi dengan kenaikan omzet penjualan hal ini menjelaskan bahwa masih rendahnya modal insani dan modal sosial yang dimiliki oleh pelaku UMKM dalam hal ini yakni UMKM sektor kuliner (Makanan dan Minuman).

Rendahnya kinerja UMKM diprediksi disebabkan oleh faktor eksternal serta faktor internal. Faktor eksternal terdiri atas kebijakan pemerintah, aspek sosial budayaekonomi, serta peran lembaga terkait seperti Pemerintah, Perguruan Tinggi, Swasta, serta LSM. Adapaun faktor internal mencakup aspek SDM (pemilik, manajer,serta karyawan), aspek keuangan, aspek teknis produksi serta aspek pemasaran (Munizu, 2010).

Kinerja pada suatu organisasi ditentukan dari sumber daya manusianya, baik unsur pimpinan maupun pekerja (Wibowo, 2010). Dalam konteks UMKM, kinerja organisasi diartikan sebagai tingkat pencapaian tujuan nan didasarkan pada tujuan nan sudah ditetapkan sebelumnya. Menurut Rapih (2015), faktor penentu pada suatu keberhasilan unit bisnis ditentukan akan kualitas SDM serta modal menyertainya. Perpaduan kualitas SDM dengan ketersediaan modal menjadikan UMKM berjalan baik serta dapat bersaing dengan pasar. Dari itu permasalahan nan mempengaruhi kinerja UMKM di Indonesia mampu diturunkan menjadi beberapa variabel, antara lain faktor modal insani serta faktor modal sosial.

Felício et al. (2014) menyatakan bahwa faktor yang mempengaruhi kinerja organisasi dalam hal ini kinerja UMKM yaitu modal insani. Nakhata (2007) menerjemahkan modal insani sebagai pengetahuan serta keahlian nan dibutuhkan untuk meningkatkan kemampuan serta kesuksesan nan diakumulasikan oleh individu sepanjang hidupnya termasuk tahun pendidikan formal serta tahun pengalaman wirausaha. Menurut Ongkorahardjo et al. (2008), modal insani merupakan gabungan atas pengetahuan, ketrampilan, inovasi serta kemampuan seseorang selama mengerjakan tugasnya sehingga mampu membuat suatu nilai agar mencapai tujuan organisasi. Dengan keterbatasan sumber daya fisik, UMKM harus bergantung pada modal insani yang dimiliki untuk mencapai kinerja yang unggul. Modal insani seperti keahlian, pelatihan, kepercayaan, pengetahuan dan pendidikan merupakan kunci sukses kinerja dari suatu Usaha (Florin et al., 2003).

Felício et al. (2014) mengatakan faktor lain nan mempengaruhi kinerja UMKM adalah modal sosial. Menurut Florin et al. (2003) modal sosial dalam anggota organisasi mampu meningkatkan kemampuan mereka dalam berbagi pengetahuan dan memberi ide di antara satu sama lain. Selain itu, modal sosial dapat meningkatkan kemampuan bisnis dalam mengumpulkan sumber daya yang dapat meningkatkan kinerja usaha. Modal sosial menurut Kim \& Aldrich (2005) dapat diperoleh melalui jaringan sosial nan dibentuk, wirausaha memperoleh terusan kepada sumber penting untuk mulainya suatu bisnis, pertumbuhan serta kesuksesannya.

Muda et al. (2016) menyatakan bahwa modal manusia berpengaruh secara signifikan dalam meningkatkan kinerja UMKM secara langsung ataupun tidak langsung. Hal ini berbanding terbalik atas penelitian yang dilakukan oleh Tessema (2015) yang hanya menawarkan dukungan untuk mendorong modal manusia pada kinerja perusahaan. Pendidikan dinilai tidak signifikan pada kinerja perusahaan dan sangat relevan dengan sistem pendidikan di Ethiopia yang hanya menekankan pada hafalan namun mengorbankan kreativitas dan kemandirian.

Akintimehin et al. (2019) menyatakan bahwa modal sosial baik dari internal maupun eksternal mempunyai pengaruh yang signifikan terhadap kinerja perusahaan. 
Didukung oleh Gelderman et al. (2016) yang menyebutkan adanya efek dari tiga dimensi modal sosial kognitif, relasional, dan struktural mendukung hubungan yang positif terhadap kinerja sosial. Berbeda dengan Khoirrini \& Kartika (2016) yang menyatakan maka dimensi relasional merupakan dimensi nan sangat disetujui saat membentuk modal sosial.

Upaya peningkatkan perkembangan kinerja UMKM tidak terlepas dari perilaku pelaku usaha yang tercermin dalam modal insani dan modal sosial. Dengan permasalahan yang tergolong baru yakni meningkatkan kinerja UMKM dalam masa pandemi Covid-19 yang belum banyak diteliti oleh peneliti sebelumnya. Oleh karenanya diperlukan adanya suatu kajian untuk menelaah pengaruh modal insani serta modal sosial. Berdasarkan masalah, uraian serta gap diatas peneliti tetarik untuk meneliti Pengaruh Modal Insani dan Modal Sosial Terhadap Perkembangan Kinerja UMKM Makanan dan Minuman Di Surabaya.

Adapun tujuan dari penelitian ini antara lain adalah : (1) Untuk mengetahui apakah modal insani berpengaruh terhadap kinerja UMKM makanan dan minuman di Surabaya, (2) Untuk mengetahui apakah modal sosial berpengaruh terhadap kinerja UMKM makanan dan minuman di Surabaya, (3) Untuk mengetahui apakah modal insani dan modal sosial berpengaruh terhadap kinerja UMKM makanan dan minuman di Surabaya.

\section{METODE}

Jenis penelitian ternasuk penelitian kuantitatif yang bertujuan agar mengetahui besarnya pengaruh secara parsial ataupun secara simultan antara modal insani $\left(\mathrm{X}_{1}\right)$, modal sosial $\left(\mathrm{X}_{2}\right)$ serta kinerja UMKM (Y).

Populasi penelitian merupakan pelaku UMKM makanan beserta minuman sentra wisata kuliner di Surabaya sejumlah 1088 UMKM. Pengambilan sampel memakai metode non probability sampling dengan teknik purposive sampling. Purposive sampling ialah teknik pengambilan sampel dengan kriteria atau pertimbangan tertentu (Sugiyono, 2016). Adapun kriteria UMKM nan dijadikan sampel pada penlitian ini antara lain : (1) UMKM yang terdaftar di Sentra Wisata Kuliner di Surabaya, (2) UMKM yang berada di Sentra Wisata Kuliner dengan rata - rata omzet tertinggi dengan cara menghitung jumlah omzet dibagi dengan jumlah pedagang aktif di setiap SWK. Untuk menghitung ukuran sampel menggunakan teknik Slovin (Sugiyono, 2016).

Berdasarkan perhitungan menggunakan teknik Slovin diatas, didapatkan sampel dalam penelitian ini sebanyak 91,58 UMKM. agar memudahkan perhitungan maka dibulatkan jadi 92 UMKM.

Pengumpulan data dilakukan menggunakan kuesioner, jumlah item pertanyaan sebanyak 33 item yang dibagi dalam 3 variabel. Variabel modal insani dengan indikator pengalaman, kemampuan professionalitas, dan kemampuan kognitif sebanyak 12 item pertanyaan, variabel modal sosial dengan indikator kemampuan membangun Kerjasama, kemampuan membangun kepercayaan, dan partisipasi dalam masyarakat lokal sebanyak 9 item pertanyaan, dan Kinerja UMKM dengan indikator pertumbuhan keuntungan, pertumbuhan jumlah pelanggan, pertumbuhan jumlah penjualan, dan pertumbuhan jumlah aset sebanyak 12 item pertanyaan. Kuesioner digunakan agar memperoleh data dari sumber data atau responden. Kuesioner berisi pernyataan yang sudah tervalidasi dan dinyatakan realiable pada setiap butir indikatornya.

Teknik analisis data pada penelitian ini dilakukan uji asumsi klasik, regresi linier berganda serta uji hipotesis. Analisis pengaruh variabel menurut parsial menggunakan uji $\mathrm{T}$, sedangkan analisis pengaruh variabel menurut simultan menggunakan uji F (Ghozali, 2016).

\section{HASIL DAN PEMBAHASAN Hasil Penelitian}

Kuisioner yang disebar merupakan instrumen tertutup memuat variabel bebas dan variabel terikat yang diteliti. Responden menjawab dengan memilih salah satu jawaban telah tersedia. Skala pengukuran nan dipakai adalah skala Likert dengan lima alternatif jawaban, diberikan skor 1 sampai 5. Variabel modal insani terdiri atas 12 item pernyataan, variabel modal sosial terdiri atas 9 item pernyataan dan variabel kinerja UMKM terdiri atas 12 item pernyataan. Semua instrumen yang digunakan telah teruji secara validitas maupun reabilitas. Data yang didapatkan selanjutnya di uji asumsi klasik, meliputi: uji normalitas, uji multikolinieritas, uji heteroskedastisitas serta uji linieritas. Uji normalitas penelitian ini menggunakan uji statistik non-parametrik Kolmogorov - Smirov. Berdasarkan pengujian normalitas data diketahui bahwa nilai Asymp. Sig (2-tailed) sebesar $0.073>0.05$ dengan demikian mampu dikatakan lolos normalitas atau data terdistribusi secara normal. Multikolinieritas dilihat dari nilai variance inflation factor (VIF) dan nilai Tolerance. Hasil analisis uji multikolinieritas menunjukkan bahwa nilai VIF $1,314<10$, serta nilai Tolerance sebesar $0,761>$ 0,1 , sehingga dinyatakan tidak terjadi multikolinieritas. Uji heteroskedastisitas menggunakan metode gletser. Hasil analisis diperoleh nilai sig. 0,510>0,05 pada variabel modal insani dan 0,293 > 0,05 pada variabel modal sosial, maka dapat disimpulkan tidak terjadi heteroskedastisitas pada model regresi yang dipakai. Hasil uji liniearitas dilihat dari nilai sig. deviation from liniearity hasilnya sebesar $0,101>0,05$, variabel modal insani berhubungan secara linier terhadap variabel kinerja UMKM serta pada variabel modal sosial juga berhubungan secara linier terhadap 
variabel kinerja UMKM dengan nilai sig. deviation from liniearity sebesar 0,438 > 0,05. Berikut merupakan hasil uji t dan uji F.

Tabel 1. Hasil Uji T.

\begin{tabular}{|c|c|c|c|c|c|}
\hline \multirow{2}{*}{\multicolumn{2}{|c|}{ Model }} & \multicolumn{2}{|c|}{$\begin{array}{l}\text { Unstandardized } \\
\text { Coefficients }\end{array}$} & \multirow[t]{2}{*}{$\mathrm{T}$} & \multirow[t]{2}{*}{ Sig. } \\
\hline & & B & $\begin{array}{l}\text { Std. } \\
\text { Error }\end{array}$ & & \\
\hline 1 & (Constant) & 18,916 & 5,169 & 3,660 & 0,000 \\
\hline & $\begin{array}{l}\text { Modal } \\
\text { Insani (X1) }\end{array}$ & 0,230 & 0,099 & 2,314 & 0,023 \\
\hline & $\begin{array}{l}\text { Modal } \\
\text { Sosial (X2) }\end{array}$ & 0,561 & 0,108 & 5,212 & 0,000 \\
\hline
\end{tabular}

Sumber : Diolah oleh SPSS 25. 2020.

Dari Tabel analisis regresi linier berganda di atas didapatkan persamaan regresinya yaitu $\mathrm{Y}=18,916+0,230 \mathrm{X} 1+0,561 \mathrm{X} 2+\mathrm{e}$.

Hasil analisis uji $\mathrm{t}$ dapat diperoleh $\mathrm{t}_{\text {tabel }}$ dengan cara $\mathrm{df}=\mathrm{n}-\mathrm{k}=92-3=89$, sehingga $\mathrm{t}_{\text {tabel }}$ dengan df 89 sebesar 1,986 . Dari table 1 memperlihatkan bahwa variabel modal insani berpengaruh secara signifikan terhadap kinerja UMKM dengan nilai $t_{\text {hitung }}=2,314>\mathrm{t}_{\text {tabel }}=1,986$ atau $\mathrm{p}$ value $=0,023$ $<\alpha=0,050$ maka Ho ditolak. Sedangkan, variabel modal sosial berpengaruh signifikan akan kinerja UMKM dengan nilai $\mathrm{t}_{\text {hitung }}=5,212>\mathrm{t}_{\text {tabel }}=1,986$ atau $\mathrm{p}$ value $=0,000<\alpha=$ 0,050 maka Ho ditolak.

Tabel 2. Hasil Uji F.

\begin{tabular}{lllll}
\hline \multirow{2}{*}{ Model } & $\begin{array}{l}\text { Sum } \\
\text { Of } \\
\end{array}$ & Squares & & Sig. \\
\hline 1 & Regression & 284,381 & 29,106 &, $000^{\mathrm{b}}$ \\
\cline { 2 - 5 } & Residual & 434,782 & & \\
\cline { 2 - 4 } & Total & 719,163 & & \\
\hline
\end{tabular}

Sumber : Diolah oleh SPSS 25. 2020.

Uji $\mathrm{F}$ statistik menunjukkan nilai $\mathrm{F}_{\text {hitung }}=29,106>$ $F_{\text {tabel }}=3,10$ signifikansi sebesar $0,000<0,05$, berarti model regresi bisa dipakai yang artinya variabel modal insani serta modal sosial secara simultan ada pengaruh yang signifikan akan variabel terikatnya yaitu kinerja UMKM.

Hasil dari regresi tersebut yaitu: variabel modal insani (X1) berpengaruh positif akan variabel kinerja UMKM (Y) dan variabel modal sosial (X2) berpengaruh positif akan variabel kinerja UMKM (Y). Uji koefisien determinasi diketahui nilai adjusted $r$-square sebesar 0,382 atau 38,2\% yang mampu disimpulkan kemampuan variabel bebas akan menjelaskan variabel terikat sebesar $38,2 \%$, serta sisanya sebesar $61,8 \%$ dijelaskan pada variabel lain nan tidak dimasukkan pada penelitian ini.

\section{PEMBAHASAN}

\section{Pengaruh Modal Insani Terhadap Kinerja UMKM Makanan dan Minuman Di Surabaya}

Berdasarkan analisis regresi linier berganda untuk menguji pengaruh variabel modal insani akan kinerja UMKM makanan serta minuman di Surabaya, didapatkan fakta bahwa menolak H0 dan menerima H1, diartikan variabel modal insani memiliki pengaruh yang positif. Besarnya ke-eratan hubungan antara variabel bebas saat menjelaskan variabel terikat sebesar 62,9\%. Besarnya sumbangan pengaruh variabel bebas terhadap variabel terikat sebesar $38,2 \%$ serta sisanya sebesar $61,8 \%$ dipengaruhi akan variabel lain. Modal insani berpengaruh signifikan terhadap kinerja UMKM makanan dan minuman di Surabaya dengan nilai $t_{\text {hitung }}=2,314>t_{\text {tabel }}=1,986$. Sehingga dapat disimpulkan, modal insani dapat meningkatkan kinerja UMKM.

Hal itu sesuai dengan Muda et al. (2016) yang menyatakan UMKM harus mengandalkan modal insani dengan atribut seperti pendidikan, pengalaman serta keterampilan untuk mencapai kinerja nan unggul. Menurut Unger et al. (2011) menyarankan usaha nan pemilik usaha serta sumber daya nan dimilikinya. Hal ini dikarenakan pendidikan, pengetahuan serta pengalaman dari pemilik mengarah kian mempengaruhi usaha secara langsung disandingkan perusahaan dengan organisasi nan kian besar.

Menurut Utami (2019) kinerja UMKM dapat meningkat melalui pengalaman kerja yang baik, kemampuan akan teknologi, dan mampu mengeksploitasi peluang.

Selain itu, berdasarkan hasil observasi dapat dilihat bahwa di sentra wisata kuliner di Surabaya yang memiliki omzet tertinggi di tahun 2020. Hal ini menunjukkan pelaku usaha yang memiliki omzet tertinggi memiliki modal insani yang tinggi. Kondisi ini juga ditemukan di Jerman, dikarenakan usaha nan dimiliki oleh pelaku usaha dengan modal insani nan kian tinggi menghasilkan pertumbuhan penjualan serta pendapatan kian tinggi dari mereka yang memiliki modal insani yang kian rendah (Moog, 2002).

\section{Pengaruh Modal Sosial Terhadap Kinerja UMKM Makanan dan Minuman Di Surabaya}

Berdasarkan hasil regresi diatas, diketahui bahwa nilai $\mathrm{t}_{\text {hitung }}=5,212>\mathrm{t}_{\text {tabel }}=1,986$ atau $\mathrm{p}$ value $=0,000<\alpha=0,050$ maka Ho ditolak dan menerima $\mathrm{H}$, artinya pada variabel modal sosial memiliki pengaruh signifikan, juga positif terhadap variabel kinerja UMKM makanan dan minuman di Surabaya. Modal sosial yang baik akan meningkatakan kinerja UMKM.

Modal sosial menjadi suatu hal yang penting pada pembangun aktivitas wirausaha. Pelaku usaha mamput menciptakan hubungan social network baik dengan 
masyarakat, agen serta pelanggan untuk menjalin ikatan feedback akhirnya terbentuk rasa saling percaya guna mendapatkan pelanggan yang loyal maupun jaringan yang luas dalam pengembangan usaha (Stam et al., 2014).

Menurut Yuwono (2016) pelaku usaha dapat meningkatkan modal sosial melalui dimensi struktural, relasional, dan dimensi kognitifnya sehingga dapat meningkatan kinerja usaha. Kinerja UMKM juga dapat ditingkatkan melalui modal sosial yang baik yaitu memiliki hubungan nan baik dengan keluarga dan lingkungan kerja, maka kinerja UMKM akan baik (Utami, 2019).

Selain itu, modal sosial merupakan sebuah kunci agar menggapai kemajuan suatu usaha. Pelaku usaha akan sulit berkembang apabila kurang pertemanan dengan pengusaha lainnya. Hasil penelitian ini juga menunjukan akan penerapan UUD 1945 pasal 33 ayat 4 yang berbunyi bahwa perekonomian Indonesia diselenggarakan atas dasar demokrasi ekonomi dengan prinsip kebersamaan berhasil dijalankan dengan baik. Kebersamaan merupakan amanat undang - undang dan wajib dilaksanakan. Dengan penguatan modal sosial akan menambah kompetensi diri, jaringan yang luas, dan Kerjasama antar pegusaha akan semakin terjaga yang nantinya akan berdampak pada peningkatan kinerja suatu UMKM.

\section{Pengaruh Modal Insani Dan Modal Sosial Terhadap Kinerja UMKM Makanan dan Minuman Di Surabaya}

Berdasarkan hasil analisa pada uji F (simultan) dengan hasil sig. sebesar $0,000<0,050$. Maka diartikan bahwa variabel modal insani serta modal sosial berpengaruh signifikan secara bersama-sama akan kinerja UMKM sebesar $38,2 \%$. Sisanya dipengaruhi dari faktor - faktor lain nang tidak dimasukkan kedalam penelitian.

Sebuah usaha pada dasarnya dibangun untuk mencapai kesuksesan. Kesuksesan tersebut akan tercapai jika penjualan terus meningkat di setiap waktunya. Peningkatan penjulan diperlukan sumber daya yang cukup untuk mendukung untuk menjalankan operasional usaha. Pelaku usaha sebagai motor penggerak wajib mempunyai modal insani dan modal sosial yang baik. Modal sosial dapat membuka jalan agar memperoleh sumber daya lain dari jaringan sosial nan dimiliki serta modal insani dapat meningkatkan kualitas dalam ber inovasi dan pengetahuan diri. Maka dapat disimpulkan semakin tinggi modal insani serta modal sosial yang dimiliki pelaku usaha akan meningkatkan kinerja usaha yang dijalankannya dalam hal ini kinerja UMKM.

Sesuai dengan pernyataan Fatoki (2011) bahwa modal insani seperti pendidikan, pengalaman, dan kompetensi dapat meningkatkan kinerja UMKM, dan juga modal sosial melalui jaringan, interaksi sosial, dan kualitas hubungan yang baik akan meningkatkan kinerja dari suatu usaha. Pernyataan tersebut sejalan dengan gagasan Munizu
(2010) yang menyatakan bahwa faktor-faktor internal yang terdiri atas aspek SDM dan aspek pemasaran mempunyai pengaruh positif dan signifikan terhadap kinerja UMKM.

Pernyataan tersebut juga diperkuat oleh Khoirrini \& Kartika (2016) menyatakan dimensi relasional merupakan dimensi nan terkuat untuk membentuk modal sosial. Dan dimensi pengetahuan dianggap paling diprioritaskan pada pembentukan modal insani. Apabila seseorang memiliki modal insani serta modal sosial yang baik maka menjadi meningkatkan kinerja UMKM.

\section{SIMPULAN}

Berdasarkan hasil analisis data nan telah dilakukan, diperoleh informasi modal insani serta modal sosial berpengaruh positif akan kinerja UMKM baik secara parsial ataupun simultan. Besarnya kontribusi pengaruh modal insani serta modal sosial terhadap minat berwirausaha sebesar $38,2 \%$, sisanya sebesar $61,8 \%$ dipengaruhi dari variabel diluar penelitian.

Penelitian ini hanya mengambil variabel modal insani dan variabel modal sosial. Oleh karena itu saran kepada peneliti selanjutnya perlu dikembangkan variabel lain yaitu variabel modal konsumen dan modal intelektual karena sesuai teori dari

\section{DAFTAR PUSTAKA}

Akintimehin, O. O., Eniola, A. A., Alabi, O. J., Eluyela, D. F., Okere, W., \& Ozordi, E. (2019). Heliyon Social capital and its effect on business performance in the Nigeria informal sector. Heliyon, 5(June), e02024. https://doi.org/10.1016/j.heliyon.2019.e02024

Badan Pusat Statistik Kota Surabaya. (2016). Berita Hasil Pendaftaran (Listing ) Usaha / Perusahaan.01, 2124.

Dinas Koperasi dan Usaha Mikro Surabaya. (2020). Renstra Perubahan Dinas Koperasi dan Usaha Mikro.

Fatoki, O. O. (2011). The Impact of Human, Social and Financial Capital on the Performance of Small and Medium-Sized Enterprises (SMEs) in South Africa. Journal of Social Sciences, 29(3), 193-204. https://doi.org/10.1080/09718923.2011.11892970

Felício, J. A., Couto, E., \& Caiado, J. (2014). Human capital, social capital and organizational performance. Management Decision, 52(2), 350364. https://doi.org/10.1108/MD-04-2013-0260

Florin, J., Lubatkin, M., \& Schulze, W. (2003). A Social Capital Model of High-growth Ventures. Academy of Management Journal, 46(3), 374-384.

Gelderman, C. J., Semeijn, J., \& Mertschuweit, P. P. (2016). Journal of Purchasing \& Supply Management The impact of social capital and technological uncertainty on strategic performance : The supplier perspective. Journal of Purchasing and Supply Management, 1-10. 
https://doi.org/10.1016/j.pursup.2016.05.004

Ghozali, I. (2016). Aplikasi Analisis Multivariate dengan Program IBM SPSS 23. Badan Penerbit Universitas Diponegoro.

Khoirrini, L., \& Kartika, L. (2016). Pengaruh Modal Insani dan Modal Sosial terhadap Kinerja (Studi Kasus Usaha Kecil dan Menengah (UKM) Makanan dan Minuman Kota Bogor). Jurnal Manajemen Dan Organisasi, $\quad 5(3), \quad 244$. https://doi.org/10.29244/jmo.v5i3.12174

Kim, P. H., \& Aldrich, H. E. (2005). Social Capital and Entrepreneurship. In Department of Sociology, University of North Carolina at Chapel Hill, NC 27599-3210, USA. Publishers Inc. https://doi.org/http://dx.doi.org/10.1561/030000000 $2 \% 0$ ASocial

Moog, P. (2002). Human Capital and ist Influence on Entrepreneurial Succes. Historical Social Research, 27(4), 157-180.

Muda, S., Ridhuan, M., \& Abdul, C. (2016). Human Capital in SMEs Life Cycle Perspective. Procedia Economics and Finance, 35(October 2015), 683689. https://doi.org/10.1016/S2212-5671(16)000848

Munizu, M. (2010). Pengaruh Faktor-Faktor Eksternal dan Internal Terhadap Kinerja Usaha Mikro dan Kecil (UMK) di Sulawesi Selatan. Jurnal Manajemen Dan Wirausaha, 12(1), 33-41. https://doi.org/10.9744/jmk.12.1.pp.33-41

Nakhata, C. (2007). The Effects of Human Capital and Entrepreneurial Competencies in the Career Success of SME Entrepreneurs in Thailand.

Noe, R. A., Hollendbeck, J. R., Gerhart, B., \& Wright, P. (2008). A to Z Human Capital. McGraw-Hill.

Ongkorahardjo, M. D. P. A., Susanto, A., \& Rachmawati, D. (2008). Analisis Human Capital Terhadap Kinerja Perusahaan. Jurnal Akuntansi dan Keuangan. 10(1), 11-21.

Rapih, S. (2015). Analisis Pengaruh Kompetensi Sumber Daya Manusia (Sdm), Modal Sosial Dan Modal Finansial Terhadap Kinerja Umkm Bidang Garmen Di Kabupaten Klaten. Jurnal Akuntansi Dan Pendidikan, 4(2), 168. https://doi.org/10.25273/jap.v4i2.685

Stam, W., Arzlanian, S., \& Elfring, T. (2014). Social capital of entrepreneurs and small firm performance: A meta-analysis of contextual and methodological moderators. Journal of Business Venturing, 29(1), 152-173. https://doi.org/10.1016/j.jbusvent.2013.01.002

Sugiyono. (2016). Metode Penelitian Kuantitatif, Kualitatif dan $R \& D$. Alfabeta.

Tessema, A. D. (2015). The Impact of Human Capital on company performance Case of the footwear Sector in Ethiopia. The Impact of Human Capital on Company Performance Case of the Footwear Sector in Ethiopia, 6.

Unger, J. M., Rauch, A., Frese, M., \& Rosenbusch, N. (2011). Journal of Business Venturing Human capital and entrepreneurial success: A metaanalytical review. Journal of Business Venturing,
26(3),

$341-358$.

https://doi.org/10.1016/j.jbusvent.2009.09.004

Utami, E. M. (2019). Peningkatan inovasi dan kinerja umkm melalui modal insani dan modal sosial. 3(November), 197-203.

Wibowo. (2010). Manajemen Kinerja. PT Raja Grafindo Persada.

World Economic Forum. (2019). The Global Competitiveness Report 2019. http://www3.weforum.org/docs/WEF_TheGlobalC ompetitivenessReport2019.pdf

Yuwono, H. D. (2016). Social Capital \& Kinerja Bisnis : Studi Kasus Pada Project. 1. 